\section{As infinitas imagens cotidianas: vínculos e excessos na imagem digital}

\author{
Ana Cláudia do Amaral Leão \\ aclaudialeao@gmail.com \\ Tese de Doutorado \\ Programa de Pós-Graduação em Comunicação e Semiótica \\ Pontifícia Universidade Católica de São Paulo \\ São Paulo (SP) 2012
}

\section{Endless everyday images: links and excesses in digital image}

\author{
Ana Cláudia do Amaral Leão \\ aclaudialeao@gmail.com \\ Doctoral Thesis \\ Post-Graduate Program in Communication and Semiotics \\ Pontifical Catholic University of São Paulo \\ São Paulo (São Paulo) - Brazil 2012
}

Esta pesquisa teve como objetivo investigar as relações e os vínculos comunicacionais entre o excesso de imagens produzidas em suporte digital e seus portadores. Parto da hipótese de que, com o advento da câmera digital e das phone cameras, o nosso modo de olhar, registrar, guardar e acessar as nossas imagens foi alterado profundamente, potencializando uma atitude viciante por imagens. Metodologicamente, o trabalho foi realizado por meio de acompanhamento e entrevistas com dez informantes, os portadores de imagens, que contribuíram para concluir que estamos produzindo, de forma exacerbada, imagens como informação. Surgem, neste cenário, os produtores de infinitas imagens cotidianas, denominadas, nesta pesquisa, de fotografadores, que geram duas naturezas de imagens: as infoimagens circulatórias e as infoimagens cotidianas. Ao produzir excessivamente imagens digitais, oferecemos aos aparelhos o caráter de extensores das nossas memórias e dos nossos esquecimentos, desfazendo a lógica de colecionar, guardar ou arquivar, e operando em uma ação acumuladora e desordenada de pequenos bancos de imagens particulares. Deste modo, tentamos saturar a nossa memória mais superficial, que, ao operar no excesso, gera imagens esquizofrênicas. No entanto, ainda que o caminho seja somente de sentido da tecnologia, precisamos relembrar que o corpo é o organismo vivo e competente às imagens, o lugar onde mantemos relações de vínculos profundos, sendo que, sobre esta superfície corpórea, as imagens sobrevivem impregnadas de sentidos, vínculos, pertença e cura. Para fundamentar as questões que permeiam a pesquisa, este trabalho aciona a teoria dos vínculos comunicacionais de Boris Cyrulnik, Jose Ângelo Gaiarsa e Ashley Montagu, além de estudos de imagens e esquizofrenia de Nise da Silveira e Leo Navratil. Na Semiótica da Cultura, em sua vertente centro europeia, foram acionadas as teorias da imagem propostas por Aby Warburg, Walter Benjamin, Dietmar Kamper, Norval Baitello Junior, Hans Belting e Vilém Flusser.
The research analyzed the relationships and communication links between overproduced images on digital media and their carriers. I start from the hypothesis that the way we look, record, save and access images have been deeply modified with the advent of digital cameras and 'phone cameras' - encouraging an addictive behavior for pictures. The method was based on interviews with ten informers - the images' carriers, who let us conclude that we are overproducing pictures as information. In this context arise the producers of endless everyday pictures, here named 'photomaniacs', who give birth two kinds of images: the circulatory infoimages and the everyday infoimages. Overproduced digital images transform devices in our magnifiers of memory and oblivion, undoing the way we compile, save or file - and operating in cumulative, disordered, small and private stock of images. Thus, we try to saturate our most superficial memory, that generates schizophrenic pictures when operates on excess. However, even if the way is only technological, we must remember that the body is the living organism suitable to pictures, the place where we hold deep bonding relations. Over this body surface, images survive impregnated of meanings, links, belonging and healing. The research was based on the theories of communication links of Boris Cyrulnik, Jose Ângelo Gaiarsa and Ashley Montagu, besides the works on images and schizophrenia of Nise da Silveira and Leo Navratil. The research also activated the central European stream of Cultural Semiotics, specially the theories of images proposed by Aby Warburg, Walter Benjamin, Dietmar Kamper, Norval Baitello Junior, Hans Belting and Vilém Flusser.

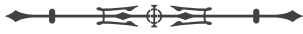

